\title{
Non-Criminalisation of Victims of Trafficking in Persons - Principles, Promises, and Perspectives
}

\author{
Andreas Schloenhardt* \& Rebekkah Markey-Towler**
}

DOI: $10.21827 / 59 \mathrm{db} 68 \mathrm{fc} 35 \mathrm{c} 13$

\begin{abstract}
Victim protection is one of the key objectives of international and domestic efforts against trafficking in persons. Existing legal instruments contain a range of mechanisms to protect the rights of victims of trafficking, providing them with material assistance, counselling, and shielding them from coercion, threats, and harm by their traffickers. An additional, more contentious protection mechanism is the principle of noncriminalisation which serves to protect victims from prosecution for offences which they may have committed during the course of their trafficking experience. The rationale of this principle is to recognise that victims often have little choice but to engage in criminal conduct during their trafficking situation and to encourage victims to cooperate with law enforcement in the investigation of their traffickers. This article examines the background and rationale of this principle, analyses existing and proposed expressions of this principle, and develops ideas and recommendations for further debate and developments in this field.
\end{abstract}

\section{Introduction}

Trafficking in persons is frequently described as a 'hidden crime' that rarely comes to the attention of the authorities and for which investigations, prosecutions, and convictions are the exception rather than the rule.1 While the true extent of this phenomenon remains unknown, there is general consensus that this crime has a considerable 'dark figure', that many if not most cases of trafficking in persons remain undetected, and that very few traffickers are ever brought to justice.2

* PhD (Adel), Professor of Criminal Law, The University of Queensland, Brisbane, Australia; Professorial Research Fellow, Department of Criminal Law \& Criminology, University of Vienna, Austria; a.schloenhardt@uq.edu.au.

** LLB/BA candidate, The University of Queensland, Brisbane, Australia. The authors wish to thank the other members of the UQ Human Trafficking Working Group for their friendship and support at the time this manuscript was taking shape. For further information visit www.law.uq.edu.au/humantrafficking.

1 Banks, D, “The U.S. Human Trafficking Reporting System: Utility and Limitations”, 81(3) International Review of Penal Law (2010) 589, 591.

2 Aronowitz, AA, "Overcoming the Challenges to Accurately Measuring the Phenomenon of Human Trafficking", 81(3) International Review of Penal Law (2010) 493, 494; Wise, M and Schloenhardt, A, "Counting Shadows - Measuring trafficking in Persons in Australia", 3 International Journal of Criminology and Sociology (2014) 249, 250. 
Traffickers often go to great length to keep their offending secret and use a range of tools to intimidate their victims such that they remain hidden and unable or unwilling to have contact with law enforcement or other authorities or to speak up to persons who could help them escape their situation of trafficking. This intimidation may involve blunt measures such as restricting the freedom of movement of victims or threatening the victims or their family should they contact the authorities. In many cases, subtle forms of control and coercion suffice to intimidate the victims and ensure that they will not report the offences that have been committed against them and talk about the exploitation they have endured.

One common and simple mechanism to control the victims involves traffickers telling their victims that the authorities will not assist them, will not believe their stories and, in particular, that the authorities will punish and/or deport the victims for crimes they may have committed during the course of their trafficking experience. The illegal status that many foreign victims of trafficking have in the destination country and the fact that they may have engaged in prohibited activities such as prostitution, working without a work permit, et cetera are circumstances with which traffickers can easily control and manipulate their victims and which create a fear that makes it less likely that victims will take the initiative to contact the authorities. Some victims are also reluctant to speak up, act, or use force against their traffickers for fear that such activities may later result in criminal charges against them.

To break this cycle of control and coercion, many international organisations, academic experts, non-governmental organisations (NGOs), and some international instruments are calling for the non-criminalisation of victims of trafficking in persons. Some variations aside, the emerging 'principle of non-criminalisation of victims of trafficking in persons' advocates that victims should not be criminalised for offences they commit during the course of their trafficking experience or for offences that are connected in some way to their status as victims of trafficking. 3

The idea here is not to confer blanket immunity upon victims, 4 but rather to strike a balance between offences committed against victims on the one hand and offences committed by victims on the other. This, it is argued, serves to maintain the interests of justice' and enhance the protection of victims of trafficking. 5

3 Gallagher, AT, The International Law of Human Trafficking (Cambridge University Press, New York, 2010) 284; Organization for Security and Co-operation in Europe (OSCE), Office of the Special Representative and Co-ordinator for Combating Trafficking in Human Beings, Report: Policy and Legislative Recommendations: Towards the Effective Implementation of the Non-Punishment Provision with regard to victims of trafficking, 2013, at <osce.org/secretariat/101002?download=true> (accessed 18 May 2016), 9; Mattar, MY, "State Responsibilities in Combating Trafficking in Persons in Central Asia", 27 Loyola of Los Angeles International and Comparative Law Review (2005) 145, 189.

4 UN Office of the High Commission for Human Rights (OHCHR), Recommended Principles and Guidelines on Human Rights and Human Trafficking Commentary, UN Doc HR/PUB/10/2, 2010, at <ohchr.org/Documents/Publications/Commentary_Human_Trafficking_en.pdf> (accessed 18 May 2016), 133. See also Court of Appeal of England and Wales, $R v N ; R v L E$ [2012] EWCA Crim 189, para 12; Court of Appeal of England and Wales, L; HVN; THN; T v R [2013] EWCA Crim 991, para 13.

5 OSCE, supra nt 3, 7; UN Conference of the Parties to the United Nations Convention against Transnational Organized Crime, Working Group on Trafficking in Persons, Report on the Meeting of the Working Group on Trafficking in Persons held in Vienna from 27 to 29 January 2010, UN Doc CTOC/COP/WG.4/2010/6 (17 February 2010), para 108. 
The non-criminalisation principle is also seen as an important tool to increase the likelihood that victims will exit their trafficking situation and cooperate freely with law enforcement and other authorities in the investigation and prosecution of their traffickers. Support for the idea of a non-criminalisation principle also comes from international law against the smuggling of migrants which does contain a - albeit very limited - clause relating to the non-criminalisation of smuggled migrants. 6

This article explores the background, rationale, scope, and operation of the principle of non-criminalisation of victims of trafficking in persons, analyses existing and proposed expressions of this principle, and develops ideas and recommendations for further debate and developments in this field. Following this introduction, Part II of this article examines the background and context of the principle and the situations and circumstances in which victims of trafficking are likely to commit criminal offences. Part III then explores the rationale and theoretical underpinnings of the principle and how it relates to existing concepts of criminal law and criminal liability. This is followed by an outline of some of the practical consequences in Part IV. Existing and proposed manifestations of the principle, their scope and application, are examined in Part V, before Parts VI and VII explore various models and limitations of the principle. Part VIII summarises the main research findings and develops ideas and recommendations for further developments and law reform in this field.

\section{Background and Context}

\section{II.1. Victims of Trafficking in Persons}

Trafficking in persons is a long-standing and worldwide phenomenon which has been recognised as a serious crime in international law. The United Nations Protocol to Prevent, Suppress and Punish Trafficking in Persons, Especially Women and Children, 7 the leading international instrument on this topic, defines 'trafficking in persons' to

"mean the recruitment, transportation, transfer, harbouring or receipt of persons, by means of the threat or use of force or other forms of coercion, of abduction, of fraud, of deception, of the abuse of power or of a position of vulnerability or of the giving or receiving of payments or benefits to achieve the consent of a person having control over another person, for the purpose of exploitation." 8

The term 'exploitation' is further defined to 'include, at a minimum, the exploitation of the prostitution of others or other forms of sexual exploitation, forced labour or services, slavery or practices similar to slavery, servitude or the removal of organs.' 9

Trafficking is a serious offence against the person that involves grave violations of fundamental human rights of persons who fall victims to this heinous crime.10

6 United Nations, Protocol against the Smuggling of Migrant by Land, Sea and Air, supplementing the Convention against Transnational Organized Crime (2004) 2241 UNTS 507 [Smuggling of Migrants Protocol], Article 5.

7 United Nations, Protocol to Prevent, Suppress and Punish Trafficking in Persons, especially Women and Children supplementing the Convention against Transnational Organized Crime (2003) 2237 UNTS 319 [Trafficking in Persons Protocol].

8 Article 3(a), Trafficking in Persons Protocol.

9 Article 3(a), Trafficking in Persons Protocol. 
Victimisation may occur in a myriad of ways and circumstances; the definition of trafficking in persons subsumes a number of practices and purposes including, inter alia, slavery, servitude (or serfdom), sexual exploitation, forced labour, debt bondage and bonded labour, servile and forced marriage, forced begging and trafficking for the purpose of organ removal.

\section{II.2. Criminal Offences Committed by Trafficking Victims}

The dire situation in which they are caught up often means that victims, because of threat, coercion, necessity, or lack of other choices, commit criminal offences during their trafficking experience. The risk of criminal offending is especially high in transit points and destination countries where victims are less familiar with local laws and customs and are thus at even greater mercy of their traffickers. From the place of origin to the destination, the risk of coming into conflict with the law permeates the entire trafficking journey and may involve, for instance, migration and border related offences as victims enter, transit, or leave different countries, often with no or with fraudulent documents. Even when they return to their country of origin, victims of trafficking may face charges for having left the country illegally, for using fraudulent documents, et cetera.11

Victims may also be forced by their traffickers to commit certain offences 'including, but not limited to, theft, pick-pocketing, drug trafficking, cannabis cultivation, and fraud.' ${ }_{12}$ The offending may also relate to the particular work victims carry out because it is prohibited (such as certain forms of prostitution) or because it requires particular work permits or licenses which victims do not hold. Further, victims of trafficking may commit criminal offences in an attempt to escape the trafficking situation, especially by using force or threats against the traffickers and those associated with them.

The following sections set out a basic typology of offences. This is by no means exhaustive but attempts to provide some categorisation of the types of offences that may be committed.

\section{II.2.1. 'Status Offences'}

Offences committed by victims of trafficking are frequently a direct result of their status in the place to or through which they have been trafficked. This is particularly relevant where trafficking occurs across international borders and where victims enter, stay, or exit from a country in violation of existing migration and border requirements.

Typically, status offences involve situations in which victims do not carry travel or identity documents required to enter, remain in, or depart from a country; in some cases they may use visas and passports that were once valid and have since expired. These offences may also arise if victims travel on fraudulent travel or identity documents which

10 OHCHR, supra nt 4, 3 .

11 UN Conference of the Parties to the United Nations Convention against Transnational Organized Crime, Working Group on Trafficking in Persons, Non-Punishment and Non-Prosecution of Victims of Trafficking in Persons: Administrative and Judicial approaches to Offences Committed in the Process of Such Trafficking, UN Doc CTOC/COP/WG.4/2010/4 (9 December 2009) 2-3, paras 5-6.

12 OSCE, supra nt 3, 9. 
are provided to them by their traffickers or other associates.13 Also falling into this category are instances in which victims or persons acting on their behalf make false representations or provide fraudulent documents such as birth certificates, documents relating to enrolments or qualifications, false marriage certificates, et cetera used to apply for visas, passports, or to deceive immigration and border control officials. Once in the countries to which they have been trafficked, victims may be forced to work in breach of the terms of their visa (for example, they may only hold tourist, visitor, or student visas). In other cases, victims are left without any documents which led them to steal documents or source fraudulent documents from elsewhere in order to flee from the traffickers. 14

In these circumstances, victims are particularly vulnerable and at risk of prosecution for immigration-related offences if apprehended by the authorities. 15 It is still common practice in many countries to arrest, punish, and deport victims of trafficking in these circumstances without giving a moment's thought to any sign that the person may have been trafficked and to the fact that the victims' illegal status may be symptomatic of much more heinous offences committed by others against these and other victims. Aware of this practice, many traffickers threaten or warn their victims that they should not seek help from the authorities as they risk being detained, punished, and returned to their place of origin. Existing laws and their enforcement thus provide a useful tool to traffickers that make it unnecessary for them to employ more blunt methods to prevent victims from escaping.

\section{II.2.2. 'Consequential Offences'}

Victims of trafficking in persons may commit one or more criminal offences because they were coerced or forced by their traffickers to do so. In such cases, it can be said that the offending occurs as a direct consequence of the the victims' situation of trafficking. Indeed, some forms of trafficking occur merely because the traffickers want to use the victim as an instrument to commit crime.

Such 'consequential offences' committed by victims often constitute the work or services for which the victims have been recruited with the trafficker intending to obtain a financial or other material benefit from such work. This would be the case, for instance, if victims engage in forms of prostitution that are illegal or if they commit theft or petty crimes under the control and to the benefit of the traffickers. Other offences subsumed in the category of consequential offences include illicit production and trafficking of drugs or the commission of violent offences at the request of traffickers. As mentioned, in some situations, the victims merely serve as agents or instruments while the traffickers are the directing minds behind the offending but without any direct involvement in the commission of individual offences. Any proceeds deriving from such crime usually have to be surrendered to the traffickers, though in some instances the victims may retain some money as a token reward or in order to discharge their debts owed to the traffickers. 16

13 OSCE, supra nt 3, 12.

14 See, for example, Court of Appeal of England and Wales, $R v O$ [2008] EWCA Crim 2835, paras 2, 10.

15 OSCE, supra nt 3, 22; OHCHR, supra nt 4, 129, 131.

16 The Netherlands, National Rapporteur on Human Trafficking, Trafficking in Human Beings: Seventh Report of the Dutch National Rapporteur, 2009, at <dutchrapporteur.nl/reports/seventh/> (accessed 18 May 2016), 218; Council of Europe, Group of Experts on Action against Trafficking in Human Beings (GRETA), $4^{\text {th }}$ General Report on GRETA's Activities covering the period from 1 August 2013 to 30 September 2014, 2013, at <refworld.org/docid/55a67bb84.html> (accessed 18 May 2016), 53; OSCE, supra nt 3, 


\section{II.2.3. 'Liberation Offences'}

A victim may also feel compelled to commit an offence in an attempt to free herself or himself from the trafficking situation or to somehow improve that situation. Such offences are not 'a direct consequence of control exerted by traffickers, but [are], still linked to the trafficking experience'.17 In most cases, these offences would be directed against the traffickers, their associates, or their property, or involve offences committed to acquire weapons, other instruments, or documents needed to leave the trafficking situation and perhaps, the host country.18

By extension, it is also conceivable that victims, in a quest to improve their situation, opt to collaborate with their traffickers and directly or indirectly, become involved in recruiting, exploiting, or receiving victims of trafficking. It is not uncommon for victims of trafficking in persons to assist their traffickers or, in some cases, gradually become traffickers themselves. Some sources refer to these situations as victims 'graduating' within their trafficking environment; a phenomenon that has most often been observed in the context of trafficking for the purpose of sexual exploitation and prostitution.19 The causes and circumstances for the transformation from victim to trafficker are extremely complex and are not well documented nor researched. While there are ample case examples from a variety of countries, in light of the limited source material it is presently not possible to make generalisations about these situations and the extent, if any, to which they are or ought to be covered by existing and proposed non-criminalisation principles.

A distinction has to been drawn between, on the one hand, (former) victims collaborating as equals with their traffickers as 'partners in crime', participants, managers (such as brothel madams), and, on the other, victims acting under compulsion or out of necessity. It has been argued that concessions and non-criminalisation should be given consideration so long as the victims 'are subordinate to the principal human traffickers and perform specific tasks for the leader or other members of the organisation.' 20 It is not uncommon for traffickers to 'manipulate their victims to turn them into their assistants in the exploitation of others' as a 'deliberate strategy to retain control over the remaining victims by placing a former victim in charge and to render them even more afraid of seeking help.' ${ }_{21}$

By contrast, 'partners-in-crime and madams operate voluntarily and play a larger role in human trafficking. The actions of the women in these categories are not directly related to their being victims' 22 and are thus not deserving of non-criminalisation.

23; OHCHR, supra nt 4, 129; See also the cases of Court of Appeal of England and Wales, $L$; $H V N$; $T H N ; T v R$ [2013] EWCA Crim 991; Court of Appeal of England and Wales, $R v N ; R v L E$ [2012] EWCA Crim 189, para 7.

17 OSCE, supra nt $3,23$.

18 The Netherlands, National Rapporteur on Trafficking in Human Beings and Sexual Violence against Children, Trafficking in Human Beings: Ninth Report of the Dutch Special Rapporteur, 2013, at $<$ dutchrapporteur.nl/reports/ninth/> (accessed 18 May 2016), 121.

19 See further, Schloenhardt, A and Jolly, J, Trafficking in Persons in Australia (LexisNexis, Sydney, 2013) $34-35$

20 Ninth Report of the Dutch Special Rapporteur, supra nt 18, 225.

21 OSCE, supra nt 3, 23.

22 Seventh Report of the Dutch National Rapporteur, supra nt 16, 225. 


\section{II.3. The Need for (Non)Criminalisation}

Applying the conventional principles of criminal law would mean that victims may be liable for a myriad of offences, some of them punishable by serious penalties, if they fulfil the physical and mental elements (actus reus and mens rea) of the relevant offence description and if they cannot rely on a defence that would exculpate them in the circumstances. If victims are found guilty, they may be subject to imprisonment and fines; if they are non-citizens, they may also be deported or unable to obtain visas to remain in the host country. 23

Seen this way, a call for the non-criminalisation of victims of trafficking seems to be at odds with established criminal law mechanisms. Non-criminalisation may appear to be unjust and inappropriate, especially if victims intentionally commit serious offences. It can be argued that existing law makes sufficient exceptions and provides adequate defences for persons acting under duress or out of necessity.

The current law, however, fails to provide fair and satisfying outcomes in many cases, with the rights of aggrieved parties (traffickers, individuals, and/or the public) being privileged over the rights of victims of trafficking in persons. Compelling victims to commit crimes is often a deliberate tactic employed by traffickers to expose victims to the risk of criminalisation.24 It prevents victims from exiting their trafficking situation as they are told that their stories will not be believed and that they will be deported and possibly incarcerated if the authorities become aware that the victim has entered the country unlawfully, has worked illegally, or has committed other offences.25 In 2010, the Working Group on Trafficking in Persons, a committee established by the Conference of States Parties to the United Nations Convention against Transnational Organised Crime, specifically stressed that:

"Criminalisation limits the trafficking victims' access to justice and protection and decreases the likelihood that they will report their victimization to the authorities. Given the victims' existing fears for their personal safety and of reprisals by the traffickers, the added fear of prosecution and punishment can only further prevent victims from seeking protection, assistance and justice." 26

\section{Theoretical Underpinnings}

The suggestion that victims of trafficking in person should not be criminalised for offences which they commit in the course of their trafficking experience can be justified in two ways: (1) It reflects general concepts of responsibility, agency, and criminal liability on which most if not all modern criminal law systems are based. (2) It serves

23 Sembacher, A, "The Council of Europe Convention on Action against Trafficking in Human Beings", 14 Tulane Journal of International \& Comparative Law (2006) 435, 451.

${ }^{24}$ OSCE, supra nt 3,9.

${ }^{25}$ OSCE, supra nt $3,10$.

26 UN Conference of the Parties to the United Nations Convention against Transnational Organized Crime, Working Group on Trafficking in Persons, Non-Punishment and Non-Prosecution of Victims of Trafficking in Persons: Administrative and Judicial approaches to Offences Committed in the Process of Such Trafficking, UN Doc CTOC/COP/WG.4/2010/4 (9 December 2009) 2-3, paras 5-6. 
multiple practical purposes to prevent and combat trafficking in persons whilst protecting victims of such trafficking.

Put differently, the non-criminalisation principle ought to balance the interest of justice with the protection of victims of trafficking. This can be achieved by recognising that in some circumstances victims may not be criminally responsible for their actions, and by facilitating the work of law enforcement and prosecutors who require the cooperation of victims in investigating and building their cases.

\section{III.1. Criminal Responsibility}

For a person to be criminally liable, the individual must be 'responsible (i.e. answerable) for something, to some person or body, within a responsibility-ascribing practice.' 27 Persons without control over their acts and omissions and persons who are incapable of making free choices because of force, threats, or deception are, generally, not responsible for any offence they may commit in these circumstances because they lack agency.

Much of the available literature advocating the non-criminalisation of victims of trafficking argues that this principle reflects the foundational concepts of responsibility and accountability,28 though provides little explanation and analysis of this argument. Using two of the principal contemporary theories on criminal responsibility, choice and character theories, the following sections serve to provide a foundation for this argument.29

\section{III.1.1. Choice Theories}

Choice theories found criminal responsibility upon capacities at the heart of human agency, namely 'cognition (knowledge of circumstances, assessment of consequences) and volition (powers of self-control).' 30 Consequently, if these capacities are substantially impaired, a person should not be held criminally liable for their conduct.

The first variant of choice theory, here referred to as 'actual choice theory', provides that punishment is justified when the offence is the product of the accused's choice to act

27 Duff, RA, Answering for Crime: Responsibility and Liability in the Criminal Law (Hart Publishing, Oxford, 2007) 15-16, 20; see also, Crofts, T and Loughnan, A, "Introduction" in Crofts, T and Loughnan, A, eds, Criminalisation and Criminal Responsibility in Australia (Oxford University Press, Melbourne, 2015) 1, 2 .

28 See, for example, OHCHR, supra nt 4, 132-133; OSCE, supra nt 3, 10; Piotrowicz, R, "The NonPunishment Principle in International Law" (paper presented at Promoting the Implementation of the NonPunishment Principle for Victims of Human Trafficking: A Workshop for Judicial and Prosecutorial Officials, Strasbourg, 9-10 October 2014), para 2; Gallagher, supra nt 3, 288; Gerry, F, "Let's Talk About Slaves ...; Human Trafficking: Exposing Hidden Victims and Criminal Profit and How Lawyers Can Help End a Global Epidemic", 3(1) Griffith Journal of Law and Human Dignity (2015) 118, 139; see also, Court of Appeal of England and Wales, L; HVN; THN; Tv R [2013] EWCA Crim 991, para 13.

29 Duff, RA, "Choice, Character and Criminal Liability", 12(4) Law and Philosophy (1993) 345, 345.

30 Lacey, N, "Space, Time and Function: Intersecting Principles of Responsibility Across the Terrain of Criminal Justice" 1 Criminal Law and Philosophy (2007) 233, 236 (Space, Time and Function); see also, Lacey N, "Responsibility and Modernity in Criminal Law" 9(3) The Journal of Political Philosophy (2001) 249, 255; Crofts and Loughnan, supra nt 27, 2. 
in a wrongful manner. 31 This, in turn, means that a person should not be held responsible if they lack choice or, in other words, if their conduct was not the product of their choice.32 The actual choice theory is, to some extent, manifested in the notion of mens rea, namely that mental elements of an offence reflect the guilt and blameworthiness of the perpetrator. 33 As a result, so-called 'innocent agents' and those operating under ignorance or honest and reasonable mistakes of fact are generally not held responsible for their conduct because they made no actual, deliberate choice to do wrong. 34 Actual choice theory does not account for instances in which the accused has intended or otherwise chosen the requisite conduct but where the criminal law nevertheless negates responsibility, such as situations of duress or self-defence, 35 which may also arise in situations of trafficking.

A second variant of choice theory, the capacity or opportunity theory, provides that 'agents should be excused if they could not have chosen to act otherwise than they did.' ${ }_{36}$ According to this theory, to be held responsible for his or her conduct, the person must, first, possess the cognitive capacity to recognise 'the relevant empirical aspects of his action and its circumstances, and of foreseeing its consequences.' ${ }_{37}$ Second, the individual must have 'fair opportunity' to choose to act differently.38 Fair opportunity is assessed not only in terms of the accused's subjective mental state, but also by looking at objective standards of conduct such as whether the individual acted reasonably in the circumstances.39 It follows that where a person's cognitive capacities are substantially impaired, for example because the persons suffers from mental impairment (insanity) or because the person is a minor, the person should not be held responsible for his or her conduct. Likewise, where a person does not have fair opportunity to act any differently, they should not be punished, for example in situations of duress or necessity.

\section{III.1.2. Character Theory}

The 'character theory' of criminal responsibility, as its name suggests, focuses less on the choice and agency of the accused and instead argues that persons are responsible for their actions only insofar as their actions reflect their character.40 According to this theory, criminal liability does not merely arise because of certain conduct or choices by the accused, but because specific conduct is seen to reflect a criminal character trait. It is these character traits, so the theory, that the 'law condemns and punishes.' 41

Character theory thus involves

31 Duff, supra nt 27.

32 Tadros, V, Criminal Responsibility (Oxford University Press, Oxford, 2010) 45.

33 Lacey, Space, Time and Function, supra nt 30, 237.

34 Duff, supra nt 27, 350.

35 Tadros, supra nt 32 65; Sistare, CT, "Models of Responsibility in Criminal Theory: Comment on Baker", 9 Law and Philosophy (1989) 295, 315.

36 Duff, supra nt 27, 354.

37 Duff, supra nt 27, 356.

38 Duff, supra nt 27, 354; Hart, HLA, Punishment and Responsibility (Clarendon Press, Oxford, 1968) 21-24; Wilson, W, Central Issues in Criminal Theory (Hart Publishing, Oxford, 2002) 112; Bayles, M,

"Character, Purpose and Criminal Responsibility" 1(1) Law and Philosophy (1982) 5, 6.

39 Lacey, Space, Time and Function supra nt 30, 237.

40 Tadros, supra nt 32, 22.

41 Duff, supra nt 27, 363. 
"an attribution of responsibility within a broader time frame than that implied by the capacity principles. For the context within which an agent has acted - a history of domestic abuse, for example - will be relevant to an evaluation of the disposition which that action expresses." 42

Such an assessment of character finds expression in objective tests of reasonableness in the law.43 Thus, for example, a person who acts under duress or in self-defence, as may be the case in situations of trafficking, should not be punished because an 'inference from criminal act $[. .$.$] to character-trait is [. .$.$] blocked.' 44$

\section{III.2. Understanding the Principle of Non-criminalisation through Theories of Responsibility}

Choice theories and character theory can provide a foundation and plausible explanation for a principle advocating the non-criminalisation of victims of trafficking in persons. This is especially the case in situations in which it can be shown that the cognitive capacity of victims, i.e. their knowledge of circumstances, their assessment of consequences, and their powers of self-control are lacking or, at a minimum, substantially impaired.45 Similarly, it can be argued that victims of trafficking carry no criminal responsibility for conduct in situations where they have no fair opportunity to act differently in the circumstances. In short, the non-criminalisation principle is based on the premise that even if a victim of trafficking deliberately commits an offence, they cannot be charged and prosecuted for that offence if they lacked true autonomy or agency at that time. To that end, 'it is crucial to understand that victims of trafficking [...] are in a situation where they have no choice but to submit to exploitation.' 46

Choice theories, however, fail to provide a comprehensive and unambiguous explanation of what makes someone's actions truly their own and therefore why such actions are worthy of punishment. 47 Also, by focusing on an individual's choice to act at a particular moment in time, these theories potentially fail to consider the broader context in which some of these actions occur. For example, in the case of victims of trafficking, their decision to act may be coloured by the history of abuse they have been exposed to. 48

There is also a risk that these theories potentially label victims of trafficking as helpless persons, incapable of making choices and free decisions and who are thus unable to take responsibility for their conduct. This approach may be offensive to many victims and may not accurately reflect their situation as trafficked persons. It fails to view victims of trafficking as 'legally competent persons with responsibility for their own acts' who may

42 Lacey, Space, Time and Function supra nt 30, 239.

43 Id, 241; Gardner, "The Gist of Excuses", 1(2) Buffalo Criminal Law Review (1998) 575, 579.

44 Duff, supra nt 27, 363.

$45 I d, 356$.

46 Inter-Parliamentary Union and United Nations Office on Drugs and Crime (UNODC), Combating Trafficking in Persons: A Handbook for Parliamentarians, 2009, at <unodc.org/documents/humantrafficking/UN_Handbook_engl_core_low.pdf> (accessed 8 May 2016), 43.

47 Duff, supra nt $27,362$.

48 Lacey, Space, Time and Function supra nt 30, 239. 
indeed make conscious decisions to commit offences, which from the victims' perspectives may be rational in the circumstances. 49

The character theory may thus provide a better and fairer explanation for the noncriminalisation of victims of trafficking. Taking into account the 'character-traits' offers a much broader insight into the duration and circumstances of the individual trafficking situation.50 According to the character theory, it can be argued that victims of trafficking who commit crimes due to their trafficking situation should not be punished because their criminal conduct does not evidence underlying criminal character. Applying this theory, however, breaks with the basic notion that criminal law serves to punish conduct, not character.

\section{III.3. Existing Concessions}

The considerations underpinning the choice and character theories find expression in the existing criminal law, for example, in the defence of duress and in the concessions made for victims of domestic violence in some jurisdictions. These defences may arise if the freedom of choice of the person is compromised and if the person's criminal conduct is not an expression of criminal character. Relevant provisions, as the following sections show, are cast very narrowly as they seek to ensure that the harm done by the victim is not disproportionate to the harm done to them. This limitation also ensures that victims are not granted blanket immunity for violent acts and other offences committed in situations involving coercion, abuse, or exploitation.

\section{III.3.1. Duress}

The defence of duress (or compulsion as it is termed in some jurisdictions) generally deals with personal crises. It is a complete defence and, if raised successfully, will result in the acquittal of the defendant. The defence operates to excuse a person from criminal responsibility where the person has committed an offence as a result of fear induced by a threat of physical harm to herself, himself, or to some other person, should she or he refuse to comply. The rationale of the defence is that 'threats of immediate death or serious personal violence so great as to overbear the ordinary power of human resistance should be accepted as justifications for acts which would otherwise be criminal'.51 The concept of duress/compulsion protects a person's freedom to choose his or her own actions. This defence arises when this choice is undermined or otherwise impaired by overwhelming factors beyond the control of the accused.52

In situations of duress, a person commits an offence under 'threat of immediate or almost immediate death or serious bodily harm' and thus should not be held responsible for their actions. .53 In such situations the individual has no fair opportunity to act

49 OSCE, supra nt 3, 10; see also, Malone, LA, "Economic Hardship as Coercion under the Protocol on International Trafficking in Persons by Organized Crime Elements", 25(1) Fordham International Law Journal (2001) 64, 67-68.

50 Lacey, Space, Time and Function supra nt 30, 239.

51 Court of Criminal Appeal of Ireland, $A G v$ Whelan (1934) 518 IR, 526.

52 O'Connor, D and Fairall, P, Criminal Defences (3rd ed, Butterworths, Sydney, 1996), para 8.2.

53 Simester, AP and Sullivan, GR, Simester and Sullivan's Criminal Law Theory and Doctrine (5th ed, Hart Publishing, Oxford, 2013), 741. 
differently, thus reflecting considerations found in choice theories. The objective elements of the defence of duress, which requires proof that a reasonable person, too, would have succumbed to the threat, further serves to demonstrate that the accused's conduct does not evince underlying criminal traits, as required by the character theory. 54

In a paper presented in 2014, Ryszard Piotrowicz draws an analogy between the defence of duress and the non-criminalisation of victims of trafficking in persons. He argues that

"[t]he idea that a trafficked person should not be punished for criminal acts in certain circumstances is really based on the appreciation that the trafficked person is not a free agent, that they are compelled to commit unlawful acts by those who control and exploit them, that they are victims of crime rather than criminals, that they are acting under duress and are in no position to object." ${ }_{55}$

In the English case of $R v L M$ and others (2010), Lord Justice Hughes notes that one of the ways in which the principle of non-punishment is implemented in England and Wales is through the defence of duress. 56 This case concerns the unrelated appeals of five women which were heard together because they shared common issues, namely trafficking in persons and the United Kingdom's obligations under the Council of Europe's Convention on Action against Trafficking in Human Beings and this Convention's non-punishment (noncriminalisation) provision, which is examined further below.

The existing defence of duress may thus serve to excuse some offences that victims of trafficking are compelled to commit by their traffickers. The defence does not have broad enough application to excuse all the possible offences a victim may have to commit to escape, endure, or survive the trafficking situation. This also - and in particular relates to offences a victim may be compelled to commit because of means other than force or threat, for example, by manipulation or psychological coercion over an extended period of time. 57

\section{III.3.2. Domestic Violence}

There are conceptual and practical similarities between victims of trafficking who try to escape from their situation by committing offences against their traffickers and victims of domestic violence who assault or kill their violent partner after years of abuse. 58 Both kinds of victims may experience physical harm, psychological abuse, coercion, exploitation, and may feel trapped in their situation, unable to see a 'way out' without harming their abuser.

54 Lacey, Space, Time and Function supra nt 30, 241.

55 Piotrowicz, R, "The Non-Punishment Principle in International Law" (Paper presented at Promoting the Implementation of the Non-Punishment Principle for Victims of Human Trafficking: $A$ Workshop for Judicial and Prosecutorial Officials, Strasbourg, 9-10 October 2014), 3.

56 Court of Appeal of England and Wales, $R v$ LM and others [2010] EWCA Crim 2327, para 8.

57 OSCE, supra nt 3, 11; Council of Europe, Explanatory Report on the Convention against Trafficking in Human Beings, CETS No 197, 16 May 2005, (accessed 8 May 2016), para 273.

58 Douglas, H, "Criminal Responsibility and Family Violence: The Relationship between (Feminist) Academic Critique and Judicial Decision-making" in Crofts, T and Loughnan, A, eds, Criminalisation and Criminal Responsibility in Australia (Oxford University Press, Melbourne 2015), 176-177. 
Traditional criminal law concepts, the defences of duress, provocation, and selfdefence in particular, can be difficult to prove for persons who assault or kill their abuser. Starting in the 1980s, a body of literature, 59 followed by a series of judicial interpretations, 60 emerged to enable more generous interpretations of these defences in favour of women who kill their abusive partners. Several jurisdictions have since amended their laws to allow for some leniency in cases where an abusive partner is killed by the victim of long-term abuse.61

The so-called 'battered woman syndrome' was first raised in Lavallee $v$ The Queen [1990] 1 SCR 852 - a Canadian case in which the female defendant shot her de facto partner who abused her for several years - in order to explain why women who kill their abusive partners do so instead of leaving the relationship. The syndrome 'purports to explain passive acceptance of violent behaviour in terms of the concept of 'learned helplessness' which is said to arise from ongoing and unpredictable violence'. ${ }_{62}$ The acceptance is often reinforced by feelings of guilt, financial dependence, and by mutual children with the abuser. The women feel unable to seek help from others for fear this may trigger further violence, which leaves them with the feeling that it is impossible to escape the dominance of the abusive partner. The Courts have admitted such 'social framework evidence' to 'explain the dynamics and effects of abuse.' 63 It shows why and how a person's capacity for choice may be impaired by domestic violence and helps to understand that a person's conduct may not reflect underlying criminal character. 64

It is arguable that similar inferences can be drawn if victims of trafficking harm their traffickers, especially if the harm caused seems disproportionate and unreasonable in isolation but becomes more plausible and explicable once the context of exploitation is taken into account.

\section{Practical Considerations}

The principle of non-criminalisation may also be justified on the basis of two practical considerations.

\section{IV.1. Breaking the Trafficker's Control}

'Success for traffickers only comes if they can control their victims.' ${ }_{65}$ Traffickers may use mechanisms to prevent victims from exiting the trafficking situation including a

59 Walker, L, The Battered Woman (Harper \& Row, New York, 1979); Walker, L, The Battered Woman Syndrome (2nd ed, Springer, New York, 1984).

60 Supreme Court of South Australia, $R v R$ (1981) 28 SASR 321; New South Wales Court of Appeal, $R v$ Hill (1981) 3 A Crim R 397; Supreme Court of South Australia, $R v$ Runjanjic and Kontinnen (1991) 56 SASR 114; Northern Territory Court of Criminal Appeal, $R v$ Secretary (1996) 5 NTLR 96.

61 See, for example, Sections 54-56 of the Coroners and Justice Act 2009; Section 304B Criminal Code (Qld); s 248 of the Criminal Code (WA); and former Sections 9AD, 9AH to the Crimes Act 1958 (Vic).

62 O'Connor and Fairall, supra nt 52, para 10.24.

63 Douglas, supra nt 58, 191.

64 Lacey, Space, Time and Function supra nt 30, 239.

65 United Nations Office on Drugs and Crime (UNODC), Anti-human trafficking manual for criminal justice practitioners, Module 4 - Control methods in trafficking in persons, New York, 2009, at <unodc.org/documents/human-trafficking/TIP_module3_Ebook.pdf> (accessed 8 May 2016), 1. 
combination of: violence and threats of violence, deception, imprisonment, collusion, debt bondage, isolation, religion, culture, and belief. Particularly relevant to the principle of non-criminalisation are situations where the traffickers tell their victims that the authorities will not assist victims, will punish them, and that officials are corrupt and cannot be trusted. These statements by the traffickers serve to frighten the victims and prevent them from making any attempts to escape. In many jurisdictions it is still common for the main focus of law enforcement investigations to rest on prosecuting victims for any offence they may have committed, rather than shifting attention to the signs of trafficking and the more heinous crimes committed to the victims. Furthermore, some victims believe the traffickers' statements because they have seen corruption firsthand or are 'aware of other victims who have been prosecuted for illegal entry or for other offences they may have been forced to commit as victims of trafficking.' 66 Hence, they may be hesitant to leave their trafficking situation.

A clear and well-known principle of non-criminalisation may encourage victims to disbelieve their traffickers and take steps to leave their control. It may also prevent traffickers from exerting 'even further control over their victims by threatening exposure to punishment by the State.' 67

\section{IV.2. Creating Incentives to Support Law Enforcement}

Prosecuting victims for offences they may have committed during their trafficking experience dissuades them from participating in the investigation and prosecution of trafficking cases.68 Accordingly, the principle of non-criminalisation may create incentives for victims of trafficking in persons to support law enforcement efforts to combat trafficking.

The prosecution of trafficking offences poses great challenges to law enforcement officials and, as mentioned earlier, investigations, prosecutions, and convictions of trafficking cases are relatively rare. One of the main obstacles is the 'reliance on often traumatised victims as witnesses who may also be unwilling or unable to participate in prosecutions.' 69 In many cases, victims are the only witnesses for the prosecution; consequently the prosecution's case is much stronger if the victim of trafficking is cooperating and willing to testify. Many prosecutors are unwilling or unable to take up cases or bring them to trial unless victims are willing to give accounts of their experiences. 70

$66 I d, 4$.

67 OSCE, supra nt 3, 10.

68 Gallagher, supra nt 3, 275; Le Cocq, P, "The Non-Punishment Principle as an Essential Element of a Human Rights-Based Approach to Action against Trafficking in Human Beings" (Presentation delivered at the Council of Europe Workshop for Judicial and Prosecutorial Officials on Promoting the Implementation of the Non-Punishment Principle for Victims of Human Trafficking, Strasbourg, 9 October 2014).

69 David, F, "Prosecuting trafficking in persons: known issues, emerging responses", 358 Trends \& Issues in Crime and Criminal Justice (2008) 1, 1.

70 Farrell, A et al, "New laws but few cases: understanding the challenges to the investigation and prosecution of human trafficking cases", 61(2) Crime, Law and Social Change (2014) 139, 157-158. 
Gaining the trust and cooperation of victims who are often severely traumatised and fearful of the authorities can be extremely difficult. 'Often, because of their distrust of police in their home countries, trafficking survivors fear law enforcement agencies and are concerned that they will be treated as criminals, incarcerated or deported.' ${ }_{71}$ Many traffickers further fuel this fear and distrust. The victims are also concerned that any cooperation with the police and other authorities will put them at risk of retaliation, threats, and harm by the traffickers - not only directed at the victims, but also against their family and friends. Slow and complex criminal proceedings often further compound these issues and deter some victims from cooperating with the authorities. 72

The principle of non-criminalisation is an important tool to address and overcome these fears and create a more collaborative and non-threatening relationship between authorities and victims. Speaking at UN Working Group on Trafficking in Persons, John Richmond, a US prosecutor of trafficking cases, stressed that 'the challenges that might result from non-prosecution were outweighed by the benefits of collaboration. Much of the evidence needed to convict traffickers came from testimony; without securing the cooperation of victims, that evidence would not be brought.' 73 A UK-based antitrafficking organisation further argues that the threat of criminalisation of victims of trafficking 'guarantees the impunity of traffickers' ${ }^{74}$ Criminalisation fails to target the real culprits of trafficking in person's cases.75 By protecting victims and promoting the principle of non-criminalisation, States are better equipped to combat, reduce, and eradicate trafficking in persons.

\section{Current State of International Law}

The principle of non-criminalisation of victims of trafficking in persons has found a mixed response in international law. Despite strong advocacy and convincing arguments by some groups and experts, some of the key international treaties in this field make no reference to non-criminalisation and make no mention of the criminal liability of victims of trafficking whatsoever. Some international documents, including binding instruments adopted by the Council of Europe and the European Union, however, promote and, in some cases, mandate the non-criminalisation or non-punishment of victims of trafficking. The following sections explore the current state of international law on this point.

71 United Nations Office on Drugs and Crime (UNODC), Toolkit to Combat Trafficking in Persons, New York,2008, at<unodc.org/documentshuman-trafficking/Toolkit-files/07-

89375_Ebook\%5B1\%5D.pdf>, 176; Bales, K and Lize, S, "Investi/gating human trafficking: challenges, lessons learned and best practices", 76(4) FBI Law Enforcement Bulletin (2007) 24, 26-27.

72 Farrell et al, supra nt 70, 157-158.

73 UN Conference of the Parties to the United Nations Convention against Transnational Organized Crime, Working Group on Trafficking in Persons, Report on the Meeting of the Working Group on Trafficking in Persons held in Vienna from 27 to 29 January 2010, UN Doc CTOC/COP/WG.4/2010/6 (17 February 2010) para 104.

74 Anti-Trafficking Monitoring Group, Rachel Annison, In the Dock: Examining the UK's Criminal Justice Response to Trafficking, ISBN: 9780900918797, June 2013, at <antislavery.org/includes/documents/cm_docs/2013/i/inthedock_final_small_file.pdf> (accessed 8 May 2016), 93.

75 OSCE, supra nt 3, 10. 


\section{V.1. UN Trafficking in Persons Protocol}

The United Nations Trafficking in Persons Protocol does not engage with criminal liability of persons who, wittingly or unwittingly, have become victims of trafficking and who may themselves have committed offences in the course of or in relation to their situation of trafficking.76 This is, perhaps, surprising, especially since another Protocol developed by the same committee at the same time, the UN Smuggling of Migrants Protocol, contains an explicit non-criminalisation principle applicable to persons who are the object of migrant smuggling. ${ }^{77}$ Several authors have criticised the Trafficking in Persons Protocol for failing to protect victims from prosecution for acts they are forced to perform.78 It has, however, been officially recognised that non-criminalisation is an essential aspect of the protection of victims of trafficking and is an extension of the Trafficking in Persons Protocol's purpose 'to protect and assist the victims of such trafficking, with full respect for their human rights'.79

\section{V.1.1. Working Group on Trafficking in Persons}

The issue of non-criminalisation was first raised in 2009 at the first meeting of the Working Group on Trafficking in Persons. In its report, the Working Group noted that:

"With regard to ensuring the non-punishment and non-prosecution of trafficked persons, States Parties should:

(a) Establish appropriate procedures for identifying victims of trafficking in persons and for giving such victims support;

(b) Consider, in line with their domestic legislation, not punishing or prosecuting trafficked persons for unlawful acts committed by them as a direct consequence of their situation as trafficked persons or where they were compelled to commit such unlawful acts." 80 that:

At the next meeting of the Working Group held in 2010 it was specifically stressed

76 See also, UN Conference of the Parties to the United Nations Convention against Transnational Organized Crime, Working Group on Trafficking in Persons, Non-Punishment and Non-Prosecution of Victims of Trafficking in Persons: Administrative and Judicial approaches to Offences Committed in the Process of Such Trafficking, UN Doc CTOC/COP/WG.4/2010/4 (9 December 2009), 3.

77 Smuggling of Migrants Protocol, Article 5; see further Schloenhardt, A and Hickson, H, "Noncriminalization of Smuggled Migrants: Rights, Obligations, and Australian Practice under Article 5 of the Protocol against the Smuggling of Migrants by Land, Sea, and Air" 25(1) International Journal of Refugee Law (2013) 39-64.

78 Hyland, KE, "The Impact of the Protocol to Prevent, Suppress and Punish Trafficking in Persons, especially Women and Children" 8(2) Human Rights Brief (2001) 30-31; Fredette, K, "Revisiting the UN Protocol on Human Trafficking: Striking balances for more effective legislation" 17 Cardozo Journal of International and Comparative Law (2009) 01-129.

79 Trafficking in Persons Protocol, Article 2(b).

80 UN Conference of the Parties to the United Nations Convention against Transnational Organized Crime, Working Group on Trafficking in Persons, Report on the Meeting of the Working Group on Trafficking in Persons held in Vienna on 14 and 15 April 2009, UN Doc CTOC/COP/WG.4/2009/2 (21 April 2009), para 12. 
"An essential element of protection of victims of trafficking and their rights must be that States do not prosecute or punish trafficked persons for trafficking-related offences such as holding false passports or working without authorization, even if they consented to hold false documents or to work without authorization. Similarly, it is argued that States should not prosecute or punish trafficked persons for crimes they may have committed in the course of trafficking. [...] Without the principle of non-liability victim assistance and support programmes are rendered ineffective and sometimes meaningless." ${ }_{81}$

At that time, the Working Group refrained from articulating the scope and wording of a non-criminalisation principle but instead pointed to the fact that offences committed by victims of trafficking under duress may be excused under existing provisions in domestic criminal law and noted that some States have adopted a 'causation based model' by which victims are not to be held liable for offences that are directly connected or related to the trafficking. 82

\section{IV.1.2. Model Law against Trafficking in Persons}

Although the Trafficking in Persons Protocol provides no express basis for the noncriminalisation of victims of trafficking, the Model Law against Trafficking in Persons, which has been developed by UNODC, the United Nations Office on Drugs and Crime, to assist States Parties with the implementation of the Protocol, suggests the inclusion of a provision on the "non-liability, non-punishment or non-prosecution of victims of trafficking in persons' in domestic law. Article 10 of the Model Law reads:

"1. A victim of trafficking in persons shall not be held criminally or administratively liable [punished] [inappropriately incarcerated, fined or otherwise penalized] for offences [unlawful acts] committed by them, to the extent that such involvement is a direct consequence of their situation as trafficked persons.

2. A victim of trafficking in persons shall not be held criminally or administratively liable for immigration offences established under national law.

3. The provisions of this article shall be without prejudice to general defences available at law to the victim.

4. The provisions of this article shall not apply where the crime is of a particularly serious nature as defined under national law."

This model provision essentially captures the three types of offences typically committed by victims during their trafficking experience: Article 10(1) covers what was earlier described as 'consequential offences' that are committed as 'a direct consequence' of the trafficking situation. Article 10(2) makes reference to offences under domestic

81 UN Conference of the Parties to the United Nations Convention against Transnational Organized Crime, Working Group on Trafficking in Persons, Non-Punishment and Non-Prosecution of Victims of Trafficking in Persons: Administrative and Judicial approaches to Offences Committed in the Process of Such Trafficking, UN Doc CTOC/COP/WG.4/2010/4 (9 December 2009), paras 10-11.

UN Conference of the Parties to the United Nations Convention against Transnational Organized Crime, Working Group on Trafficking in Persons, Non-Punishment and Non-Prosecution of Victims of Trafficking in Persons: Administrative and Judicial approaches to Offences Committed in the Process of Such Trafficking, UN Doc CTOC/COP/WG.4/2010/4 (9 December 2009), para 11. 
immigration law which were earlier referred to as 'status offences'. Offences committed under duress or out of necessity, including 'liberation offences', ought to be covered by general defences as recognised by Article 10(3). To ensure, that this non-criminalisation provision does not provide a 'blank cheque' for committing heinous crimes, Article 10(4) limits the application to offences that are not 'particularly serious offences as defined under national law'.

\section{V.2. Council of Europe Convention on Action against Trafficking in Human Beings}

The Council of Europe Convention on Action against Trafficking in Human Beings, which came into existence in 2005,83 mirrors the provisions and obligations under the UN Trafficking in Persons Protocol in many ways but expands several of its concepts, especially with regard to the protection of victims. Besides the Trafficking in Persons Protocol, with 44 States Parties the Council of Europe Convention is the most widely accepted, binding international instrument on this topic.

Article 26 of the Convention contains a 'non-punishment provision' which states that:

"Each Party shall, in accordance with the basic principles of its legal system, provide for the possibility of not imposing penalties on victims for their involvement in unlawful activities, to the extent that they have been compelled to do so."

The Explanatory Report on the Convention further notes that

"Article 26 constitutes an obligation to Parties to adopt and/or implement legislative measures providing for the possibility of not imposing penalties on victims, on the grounds indicated in the same article.

In particular, the requirement that victims have been compelled to be involved in unlawful activities shall be understood as comprising, at a minimum, victims that have been subject to any of the illicit means referred to in Article 4, when such involvement results from compulsion.

Each Party can comply with the obligation established in Article 26, by providing for a substantive criminal or procedural criminal law provision, or any other measure, allowing for the possibility of not punishing victims when the above mentioned legal requirements are met, in accordance with the basic principles of every national legal system." ${ }_{84}$

Unlike the UNODC Model Law, the non-punishment provision under Article 26 and the explanatory notes give little guidance on the type of offences for which victims of trafficking should not be criminalised. Some reference is made to offences committed under duress or compulsion and there is a call on States Parties to use general criminal law provisions, i.e. defences, to excuse victims in these circumstances. The main

83 Opened for signature on 16 May 2005, Council of Europe Treaty Series No. 197 (entered into force 1 February 2008).

84 Council of Europe, supra nt 57, paras 272-274. 
emphasis in the Article and the Explanatory Report is on offences the victims was compelled to commit. This would not immediately extend to offences committed by the victim to liberate herself or himself from the trafficking situation as these offences would not be committed under the compulsion of the traffickers. From the plain wording, it is also unclear whether the provision extends to what was earlier described as 'status offences', especially in circumstances in which the victim knowingly enters or stays in the host country in violation of domestic immigration and residence laws.

\section{V.3. European Union Council Directive and Framework Decision}

The European Union's initial documents to combat trafficking in persons, Council Joint Action 97/154/JHA of 24 February 1997 and Council Framework Decision 2002/629/JHA of 19 July 2002, made no specific reference to the non-criminalisation of victims. The issue was first raised at the European Conference on Preventing and Combating Trafficking in Human Beings, held from 18 to 20 September 2002, which developed a set of 'recommendations, standards, and best practices', later referred to as the Brussels Declaration on Preventing and Combating Trafficking in Human Beings.85 In the context of 'victim protection and assistance', this Declaration specifically notes that:

"Trafficked victims must be recognised as victims of serious crime. Therefore they should not be re-victimised, further stigmatised, criminalised, prosecuted or held in detention centres for offences that may have been committed by the victim as part of the trafficking process."

In 2011, the European Union revised its efforts against trafficking in persons and issued Directive 2011/36/EU of the European Parliament and of the Council of 5 April 2011 on preventing and combating trafficking in human beings and protecting its victims, and replacing Council Framework Decision 2002/629/JHA. This Directive provides extensive guidance to Member States on the necessary steps to criminalise trafficking, for effective law enforcement, and for the assistance and support to victims of trafficking. Article 8 of this Directive specifically addresses the non-criminalisation principle:

"Article 8 -Non-prosecution or non-application of penalties to the victim

Member States shall, in accordance with the basic principles of their legal systems, take the necessary measures to ensure that competent national authorities are entitled not to prosecute or impose penalties on victims of trafficking in human beings for their involvement in criminal activities which they have been compelled to commit as a direct consequence of being subjected to any of the acts referred to in Article 2."

This provision makes specific reference to criminal activities which victims 'have been compelled to commit as a direct consequence of being a victim'. A plain reading suggests that this extends to offences committed under duress and to offences committed under the control of the traffickers. Article 8 does not specifically call on Member States not to criminalise offences committed in these circumstances; instead, it advocates that prosecution and judicial authorities exercise discretion in their decision to prosecute or

85 Council of the European Union, Brussels Declaration on Preventing and Combating Trafficking in Human Beings, 14981/02 (29 November 2002) Annex. 
punish or to refrain from prosecution and punishment. To that end, Article 8 does not mandate or propose amendments to substantive criminal laws but merely calls for the adoption of measures that entitle relevant authorities to exercise discretion as they see appropriate in the circumstances.

\section{V.4. Other United Nations Declarations and Guidelines}

\section{V.4.1. UNHCHR Recommended Principles and Guidelines on Human Rights and Human Trafficking}

The non-criminalisation principle has also been articulated in a range of United Nations declarations, resolutions, and guidelines issued over the past 16 years. One of the first and most frequently cited expressions of the principle can be found in the Recommended Principles and Guidelines on Human Rights and Human Trafficking that were first published by the United Nations Office of the High Commissioner for Human Rights (UNHCHR) in 2002.86 Principle 7 specifically states that:

"Trafficked persons shall not be detained, charged or prosecuted for the illegality of their entry into or residence in countries of transit and destination, or for their involvement in unlawful activities to the extent that such involvement is a direct consequence of their situation as trafficked persons."

This principle is further explained in additional 'Guidelines', which call on States, intergovernmental and non-governmental organisations to consider:

"Ensuring that trafficked persons are not prosecuted for violations of immigration laws or for the activities they are involved in as a direct consequence of their situation as trafficked persons.

Ensuring that trafficked persons are not, in any circumstances, held in immigration detention or other forms of custody. [...]

Ensuring that legislation prevents trafficked persons from being prosecuted, detained or punished for the illegality of their entry or residence or for the activities they are involved in as a direct consequence of their situation as trafficked persons. [...]

Guaranteeing that traffickers are and will remain the focus of anti-trafficking strategies and that law enforcement efforts do not place trafficked persons at risk of being punished for offences committed as a consequence of their situation. [...]

Ensuring that children who are victims of trafficking are not subjected to criminal procedures or sanctions for offences related to their situation as trafficked persons." 87

Principle 7 is a very broad expression of the non-criminalisation principle insofar as it extends to status and consequential offences. The Guidelines further stress that victims of

86 OHCHR, supra nt 4.

$87 I d$, Guidelines 2.5, 2.6, 4.5, 5.5, 5.6. 
trafficking should not be detained in any way for their offending insofar as this relates to their status or to offences committed as a direct consequence of their trafficking situation.

\section{V.4.2. UN General Assembly}

Starting in 2000, several UN General Assembly resolutions also call upon States to refrain from criminalising and punishing victims of trafficking in persons. The first of these resolutions was made in the context of promoting the rights of and empowering women. Here, the General Assembly recommended that Member States

"[c]onsider preventing, within the legal framework and in accordance with national policies, victims of trafficking, in particular women and girls, from being prosecuted for their illegal entry or residence, taking into account that they are victims of exploitation." 88

In Resolution 65/190 of 21 December 2010, the General Assembly further

"urges Governments to take all appropriate measures to ensure that victims of trafficking are not penalized or prosecuted for acts committed as a direct result of being trafficked and that they do not suffer from revictimization as a result of actions taken by Government authorities, and encourages Governments to prevent, within their legal framework and in accordance with national policies, victims of trafficking in persons from being prosecuted for their illegal entry or residence." 89

The same statement was reiterated in a General Assembly resolutions made in 2012.90 A further 2014 resolution expands this call for action by

"[urging] Governments, in accordance with their respective legal systems, to take all appropriate measures, including through policies and legislation, to ensure that victims of trafficking are protected from prosecution or punishment for acts those victims have been compelled to commit as a direct consequence of having been trafficked and that the victims do not suffer from revictimization as a result of actions taken by Government authorities, and encourages Governments to prevent, within their legal framework and in accordance with national policies, victims of trafficking in persons from being prosecuted or punished as a direct consequence of their illegal entry or residence." ${ }_{91}$

\section{V.4.3. ILO 2014 Protocol to the Forced Labour Convention}

The non-criminalisation principle has recently been added to international efforts by the International Labour Organisation (ILO) to fight labour trafficking and forced labour.

88 UN General Assembly, Further Actions and Initiatives to Implement the Beijing Declaration and Platform for Action, UN Doc A/RES/S-23/3 (16 November 2000), para 70(c).

89 UN General Assembly, Trafficking in women and girls, UN Doc A/RES/65/190 (21 December 2010), para 17.

90 UN General Assembly, Trafficking in women and girls, UN Doc A/RES/67/145 (20 December 2012), para 20.

91 UN General Assembly, Trafficking in women and girls, UN Doc A/RES/69/149 (18 December 2014), para 25. 
In 2014, a new Protocol to the Forced Labour Convention was adopted to suppress all forms of forced labour, protect victims, and to take effective measures to prevent forced labour.92 Article 4(2) of the Protocol states that:

"Each Member shall, in accordance with the basic principles of its legal system, take the necessary measures to ensure that competent authorities are entitled not to prosecute or impose penalties on victims of forced or compulsory labour for their involvement in unlawful activities which they have been compelled to commit as a direct consequence of being subjected to forced or compulsory labour." 93

\section{V.5. Other Regional Instruments}

The non-criminalisation principle has also been recognised in recommendations made by regional organisations in Europe and the Americas. This includes the Action Plan to Combat Trafficking in Human Beings developed by the Organisation for Security and Cooperation in Europe in 2003, which calls on Member States to ensure 'that victims of trafficking are not subject to criminal proceedings solely as a direct result of them having been trafficked' .94

The 2006 Conclusions and Recommendations of the Meeting of National Authorities on Trafficking in Persons by the Organisation of American States (OAS) provide that

"Member States must ensure, to the extent possible and in accordance with their respective domestic legislations, that the victims of trafficking in persons are not prosecuted for participating in illegal activities if they are the direct results of their being a victim of such trafficking." 95

The Conclusions and Recommendations of the 2009 meeting further call on Members States

"to avoid, in accordance with domestic laws and jurisprudence, the detention, criminal prosecution, and punishment of victims of trafficking in persons for their participation in illegal activities, to the extent that such participation was the direct result of their being the victims of trafficking and to the extent that the victims were forced or compelled to participate in such activities." ${ }_{96}$

92 Protocol of 2014 to the Forced Labour Convention, opened for signature 11 June 2014, ILO PO No 29 (not yet in force).

93 Protocol of 2014 to the Forced Labour Convention, opened for signature 11 June 2014, ILO PO No 29 (not yet in force), Article 4(2).

94 OSCE, Action Plan to Combat Trafficking in Human Beings, MC Dec 2/03, OSCE, MC.DEC/2/03 (2 December 2003), recommendation 1.8.

95 Permanent Council of the Organisation of American States, Conclusions and Recommendations of the Meeting of National Authorities on Trafficking in Persons, $1^{\text {st }} \mathrm{mtg}$, OEA/Ser.K/XXXIX (26 April 2006) Section IV(7).

96 Permanent Council of the Organisation of American States, Conclusions and Recommendations of the Second Meeting of National Authorities on Trafficking in Persons, $2^{\text {nd }}$ mtg, OEA/Ser.K/XXXIX.2 (18 September 2009), recommendation 21. 


\section{Scope of the Principle}

The existing provisions in international law vary in the way they articulate the noncriminalisation principle. Differences can be seen in the scope and subject of the provisions, and, importantly, in the causal connection between offence and the victim required for the principle to apply.

\section{VI.1. Non-criminalisation, Non-prosecution, Non-punishment}

At the outset, the various articulations of the principle differ in the terminology used, with some referring to 'non-criminalisation', others to 'non-prosecution', and others still to 'non-punishment'. Although these differences seem small and subtle, they have implications for the scope of the principle and the question what precisely victims are to be protected from.

'Non-criminalisation' is the broadest of the terms used. This seems to advocate that criminal liability does not arise in the first place and that the exemption made for victims of trafficking is not merely a matter of discretion or defences. A literal reading of the term would suggest that offences committed by victims of trafficking are not illegal and do not require prosecution and punishment. Non-criminalisation would thus provide the widest protection for victims. The term can mostly be found in the academic literature and is not used in any of the binding international instruments.97 Only Article 10 of UNODC's Model Law refers to 'non-liability' of victims and provides that victims of trafficking in persons should not be held 'criminally or administratively liable for offences' they may commit in the course of trafficking. Because of the breadth of the application, the Model Law is qualified by the requirement in Article 10(4) that non-liability does not apply 'where the crime is of a particularly serious nature as defined under national law'.

The term 'non-prosecution' which is used in Article 8 of the European Union Directive and in Article 4(2) of the ILO 2014 Protocol to the Forced Labour Convention has a much narrower meaning and specifically refers to the possibility that prosecutors may refrain pressing charges against victims of trafficking. The way in which the term 'nonprosecution' is used here does not alter the criminality or illegality of the victims' conduct and instead suggest that whether victims will face prosecution and punishment for any offence committed as part of the trafficking situation is a matter of discretion and decided on a case-by-case basis ('entitled not to prosecute'). This is especially problematic in civil law jurisdictions where, in some systems, authorities have a duty (and no discretion) to prosecute. Even where the discretion not to prosecute exists, this creates some uncertainty for victims of trafficking as they are unaware of the consequences they may face should they report to the authorities. It also leaves open the possibility that a decision not to prosecute may be reversed.98 The UNHCHR Recommended Principles and Guidelines, the UN General Assembly Resolutions of 2010 and 2012 and the OAS

\footnotetext{
97 Hoshi, B, “The Trafficking Defence: A Proposed Model for the Non-Criminalisation of Trafficked Persons in International Law", 1(2) Groningen Journal of International Law (2013) 54.

98 Id, 54, 59 .
} 
Conclusions and Recommendations of 2006 and 2009 also refer to non-prosecution but use the term in a non-discretionary way ('must ensure that ... are not prosecuted').

The term 'non-punishment' of victims of trafficking only refers to the sanctions that victims may face for their offending. It does not engage with the question of whether such offending is illegal and ought to be criminalised; a non-punishment principle merely calls on States to refrain from imposing criminal sanctions, such as fines and imprisonment, on victims for offences they have committed as part of their trafficking experience. Article 26 of the Council of Europe Convention is limited in this way; at a minimum, this Article only requires that States Parties 'provide for the possibility of not imposing penalties on victims'. In other words, the Article calls upon States to refrain from punishment but does not discourage criminalisation and prosecution. The UNODC Model Law, the European Union Directives and the UN General Assembly resolutions also advocate the non-penalisation/non-punishment of victims, but do so in addition or as an alternative to non-prosecution or non-criminalisation.

The question thus arises to what extent leniency for offences committed by victims of trafficking should be exercised and whether this is a matter of deciding in individual cases that the person may not be liable, not be prosecuted, or not punished, or whether there is an underlying rule exempting victims from criminal liability altogether so long as their offending occurred in the course or as a consequence of their trafficking experience. International law has thus far been rather cautious in its approach but this caution may be too little to signal to victims that they can exit their trafficking situation and freely cooperate with law enforcement agencies without fear. Discretionary non-prosecution and non-punishment may give many victims too little certainty that they will be believed and not face consequences for offences they had to commit.

\section{VI.2. Subject of the Provision}

In the existing expressions of the principle there is some variation regarding its subject, with some referring to 'victims of trafficking' and others to 'trafficked person'; two terms that are used quite interchangeably throughout the literature.

'Victims of trafficking in persons', the term also used earlier in this paper, are not further defined in the UN Trafficking in Persons Protocol. The UNODC Model Law promotes the adoption of such a definition in domestic law and broadly defines the term to include 'any natural person who has been the subject of trafficking in persons or whom the competent authorities [...] reasonably believe is a victim of trafficking in persons, regardless of whether the person is identified, apprehended, prosecuted or convicted'. 99

This definition reflects Article 4(e) of the Council of Europe Convention on Action against Trafficking in Human Beings as well as the definition of 'victim' set out in the UN Declaration of Basic Principles of Justice for Victims of Crime and Abuse of Power. The latter refers to victims as

99 Article 5(v), UN Office on Drugs and Crime (UNODC) and UN.GIFT. Model Law against Trafficking in Persons (2009) [Model Law against Trafficking in Persons]. 
"persons who, individually or collectively, have suffered harm, including physical or mental injury, emotional suffering, economic loss or substantial impairment of their fundamental rights, through acts or omissions that are in violation of criminal laws operative within Member States, including those laws proscribing criminal abuse of power." 100

While these definitions shed some light into the category of persons who fall under the non-criminalisation principle in its various articulations, there are considerable practical difficulties in identifying victims and determining victim status with certainty.101 Furthermore, there is continuing discussion and controversy about the point in time at which that determination is to be made, which is important as this also determines when a person can benefit from protection and assistance mechanisms, including the noncriminalisation principle.

To be considered a victim of trafficking under the Council of Europe Convention, for instance, it suffices that the competent authorities have 'reasonable grounds to believe that a person is a victim'. The Convention awards certain rights and protection before victim status has been formally assigned; it 'does not require absolute certainty [which is] by definition impossible before the identification process has been completed' ${ }_{102}$ The Model Law similarly makes reference to a reasonable belief that a person 'is a victim of trafficking in persons, regardless of whether the person is identified, apprehended, prosecuted or convicted'. .103

It is unclear and debatable at what point persons presumed, but not confirmed, to be victims should benefit from the non-criminalisation principle and the existing material is mute on this point. The decisions of if and when to investigate and prosecute a person believed to be a victim ultimately rest with States and their authorities. Long delays and waiting periods may not be in the interest of justice and may create a risk that information and evidence will become unavailable. On the other hand, to best serve the non-criminalisation principle and avoid further traumatisation of victims, prosecutions ought to be delayed so long as the authorities reasonably believe that the person may be a victim. It would be advisable to issue further guidance for States and their authorities on this point.

\section{Compulsion, Causation, Consequences}

The most challenging aspect of the non-criminalisation principle is the nexus between the trafficking situation and the offence the victim committed in that situation. Expressions such as 'as part of', 'in the course of', 'in furtherance of', 'as a consequence of', and 'compelled to do' all serve to establish some causal connection between the position of a victim of trafficking on the one hand and the offending on the other. Just how this connection is framed and what proof it requires is, perhaps, the most contentious aspect of the non-criminalisation principle. 104 In the existing laws and

\footnotetext{
${ }^{100}$ UN General Assembly, Declaration of Basic Principles of Justice for Victims of Crime and Abuse of Power, 29 November 1985 , $\left(96^{\text {th }}\right.$ plenary meeting) A/RES/40/34, Annex, paras 1-2.

101 Gallagher, supra nt 3, 277.

102 Council of Europe, supra nt 57, paras 131-132.

103 Article 5(v), Model Law against Trafficking in Persons, supra nt 99.

${ }^{104}$ Hoshi, supra nt 97, 54, 68.
} 
literature, three separate models for this connection can be identified which are generally referred to as the compulsion, causation, and presumption models.

\section{VII.1. Compulsion Model}

The compulsion model limits non-criminalisation, non-prosecution or nonpunishment to offences that victims were forced, coerced or otherwise compelled to commit and 'requires that the criminal act is committed under a high degree of pressure from the trafficker(s).' 105 The model thus primarily emphasises existing notions of duress, discussed earlier in this article, and the fact that freedom of choice of the victim is significantly impaired in these circumstances, such that they lack true autonomy and agency.106 It has been argued, however, that the compulsion model is not merely a restatement of the established defence of duress, but that it uses the means element in the definition of trafficking persons, such as threat or use of force, other forms of coercion, abduction, fraud, deception or abuse of power or of a position of vulnerability, to explain and excuse offences committed by the victim while these means are present.107

This compulsion model is reflected in Article 26 of the Council of Europe Convention which advocates non-punishment for 'involvement in unlawful activities, to the extent that [victims] have been compelled to do so'. Article 8 of the European Union Directive and the ILO 2014 Protocol contain the same phrase but qualify it further by requiring 'a direct consequence of being' a victim of trafficking.

The compulsion model has been criticised for being too narrow and for failing to meet the objectives of the non-criminalisation principle. Bijan Hoshi argues that the compulsion model

"fails to grasp the subtle and nefarious methods by which traffickers can exert total dominance over trafficked persons, such that even in the absence of a high degree of pressure (or, indeed, any overt pressure at all), the trafficked person may, in reality, have little choice but to commit the criminal act." 108

This model may also provide insufficient protection of victims from criminalisation and punishment for immigration and status offences and for 'liberation offences', which the victim commits at her or his own initiative and not under the control or compulsion of the traffickers.

\section{VII.2. Causation Model}

The causal connection between the trafficking situation and the offending are the principal focus of the causation model of non-criminalisation. This model extends noncriminalisation, non-prosecution or non-punishment to offences committed 'as a direct consequence' of being a victim of trafficking. Unlike the compulsion model, this approach does not require the nexus to any force, coercion or duress exercised by the traffickers and thus provides a potentially greater scope of application.

\footnotetext{
105 Id, 54 .

${ }^{106}$ OSCE, supra nt $3,10$.

${ }^{107}$ Id, 10, 27; Anti-Trafficking Monitoring Group (ATMG), In the Dock: Examining the UK's Criminal Justice Response to Trafficking (2013) 95; Council of Europe, supra nt 57, para 273.

${ }^{108}$ Hoshi, supra nt 97, 54, 55.
} 
Reference to the causation model can be found in the UN Working Group on Trafficking in Persons, the UNODC Model Law, and the UNHCHR Recommended Principles and Guidelines, which all refer to offences committed 'as a direct consequence' of the trafficking situation. The reference to 'a direct result of them having been trafficked' in the OSCE Action Plan can be understood in the same way. During the development of the Council of Europe Convention, the Parliamentary Assembly of the Council also recommended that the Convention's non-punishment provision be expressed in causation/consequence terms; 109 a suggestion that was ultimately rejected in favour of the compulsion model. The European Union Directive and the ILO 2014 Protocol also use the phrase 'as a direct consequence of' but, as mentioned, additionally require the compulsion element.

The broader and seemingly more flexible application of the causation model has been praised for providing 'effective and sufficient' protection to trafficked persons.110 It is, however, not surprising that this model has not been adopted in the binding, more authoritative expressions of the non-criminalisation principle. There is a valid concern that, while in theory the causation model meets the objectives of the non-criminalisation principle better, it is over-inclusive and difficult to operate in practice. In particular, statements of the causation model fail to articulate clear boundaries of where the causal or consequential nexus between the trafficking situation and the offending ends, and where full responsibility of the offender begins.

\section{VII.3. Presumption Model}

A third model that has found very limited adoption and lacks a wider theoretical foundation is the presumption model. This takes a very pragmatic and clear-cut approach to the questions of liability and criminalisation. The approach plainly exempts victims of trafficking from certain offences or presumes that they will be not be liable, criminalised or punished, unless it can be established that the victims' offending is unrelated to their situation of trafficking.

Article 10(2) of the UNODC Model Law, for instance, adopts this approach when it states that 'a victim of trafficking in persons shall not be held criminally or administratively liable' but limits this exception to immigration offences. Similarly, the UNHCHR Recommended Guidelines and Principles state that 'trafficked persons shall not be detained, charged or prosecuted for the illegality of their entry into or residence in countries of transit and destination'.

This model is not suitable for wider adoption and has thus not found further support - and indeed much discussion - in the literature and by relevant international organisations. It can, however, serve to make exemptions or concessions or establish presumptions for specific offences, especially immigration and other status offences. It provides the most blunt and most clear message to victims that they will not be criminalised, prosecuted and punished for certain offences and, in the context of

\footnotetext{
${ }^{109}$ Parliamentary Assembly of the Council of Europe, Draft Council of Europe Convention on Action against Trafficking in Human Beings, 26 January 2005, Opinion 253 para 14, section xvi.

$110 I d$, para 8.
} 
immigration offences, may create a real incentive for victims to exit their trafficking situation and make themselves known to the authorities. It is, however, unsuited for more complex offending and for serious offences resulting in harm or other detriments to persons.

\section{Conclusion}

The non-criminalisation of victims of trafficking in persons for offences they commit during their trafficking situation is a contentious issue and a topic that remains in flux and requires further consideration and development. There is, at present, no clear, uniform and universal articulation of this concept and it is premature to speak of an established principle, ready for implementation into domestic laws worldwide. The existing statements of non-criminalisation, non-prosecution, and non-punishment of victims of trafficking also differ substantially in their scope and application.

There is, however, greater and growing recognition of the fact that victims of trafficking frequently have little choice but to engage in criminal conduct and of the fact that existing criminal and anti-trafficking laws inadequately protect victims from the threat of criminal prosecution and from detention and deportation.

In the medium and long-term it would be desirable to further discuss and develop a uniform principle of non-criminalisation that is recognised in international law and adopted widely in national systems. The existing expressions of the principle share some commonalities and provide a platform for further debate on this issue. Further research is also needed on the scope and operation of the non-criminalisation principle in those jurisdictions where it is already enshrined in domestic law.

The main challenge is to articulate a model that balances the interests of justice with the protection of the victims of trafficking. This model needs to be expressed in no uncertain terms so that it sends a clear message to victims that they can exit the trafficking situation without having to be fearful of interaction with and further traumatisation by the authorities. At the same time, the model cannot provide blanket immunity, especially if serious offences have been committed. The further development and implementation of a non-criminalisation principle needs to go hand in hand with clear and improved mechanisms to identify victims of trafficking and protect them from further trauma and from threats and harm by their traffickers.

The threshold required to establish a causal connection between the offences committed against victims and those committed by them is a further challenge in the development of a non-criminalisation principle. The 'compulsion model', which has found some recognition and adoption in international and domestic laws, is too narrow to address the relevant concerns. The 'causation model', on the other hand, remains somewhat vague and potentially over-inclusive. Further work needs to be done to develop a model that reconciles these two approaches. One idea here, which is still in its infancy and lacking wider support, is the creation of a specific trafficking defence that is cast for the specific situations in which victims should be excused for committing offences because of their trafficking experience.111 The specific requirements and elements

\footnotetext{
${ }^{111}$ Hoshi, supra nt 97, 54, 70.
} 
of such a defence have yet to be explored and articulated, though the newly emerging domestic violence defences mentioned earlier may serve as a template for further discussion.

The weight of authoritative opinion persists in the view that existing criminal law, the defences of duress and necessity in particular, provide adequate solutions in most cases. Prosecutorial discretion and the mitigation of sentences are further avenues to avert criminal liability or reduce sentences for victims who have committed criminal offences. The non-criminalisation principle still faces major opposition and much work needs to be done to demonstrate that the status quo provides traffickers with a tool to coerce and threaten their victims and to show that victims are often rightfully reluctant to cooperate with the authorities for fear that they themselves may become the subject of investigations, prosecutions and deportations. It is hoped that this article serves to convince some critics that change is needed and that the article provides a small step towards protecting victims of trafficking in persons more effectively in the future.

\section{www.grojil.org}

